Оригинални научни рад

УДК 821.163.41.09-31 Булатовић М.

Примљен: 31. марта 2021.

Прихваћен: 5. маја 2021.

Христина Љ. Аксентијевић ${ }^{1}$

https://doi.org/10.46630/phm.13.2021.17

Универзитет у Нишу

Филозофски факултет

Департман за србистику

\title{
БУЛАТОВИЋЕВА ЛОГИКА ФИКЦИЈЕ: МОГУТИ СВЕТОВИ У РОМАНИМА ХЕРОЈ НА МАГАРЦУ И РАТ ЈЕ БИО БОљИ МИОДРАГА БУЛАТОВИЋА
}

\begin{abstract}
Предмет истраживања у овом раду јесте издвајање и анализирање фикционалних светова и ликова који их настањују у наведеним Булатовићевим романима, ослањајући се на основне постулате теорије могућих светова и радове водећих аутора који се баве овом облашћу у науци о књижевности. Тема пружа бројне могућности иновације, јер се бави недовољно истраженим аспектима Булатовићеве прозе, који остају изван фокуса књижевнокритичке литературе. Корпус проучавања чини романескни диптих сачињен од романа Херој на магариу (1967) и Рат је био бољи (1969) које, у контексту поменуте методолошке основе, сагледавамо као фикционалну целину обухваћену релацијом између једног матичног фикционалног света и његовог текстуалног сукцесора. Основно методолошко усмерење представљају класичне и посткласичне наратолошке студије, са посебним фокусом на когнитивна наратолошка истраживања.
\end{abstract}

Кључне речи: теорија могућих светова, фикционални свет, нестварне јединке, метафикција, роман, Булатовић

1. Логика фикције; Фикционални светови књижевности и могући светови формалне семантике

Теорија могућих светова своју основу има у модалној логици, а потиче још из Лајбницове (Gottfried Wilhelm Leibniz) теорије и његовог учења о мноштву светова који постоје у божанском уму, од којих је наш свет најбољи и, због тога, једини актуализован. Идеја о могућим световима постаје посебно актуелна и истраживана шездесетих година двадесетог века у оквиру семантике могућих светова. Тај концепт ће, кроз радове Сола Крипкеа (Saul Kripke), Дејвида Луиса (David Lewis), Николаса Решеpa (Nicholas Rescher), Роберта Сталнакера (Robert Stalnaker) и других, до-

1 hristina.aksentijevic@filfak.ni.ac.rs 
бити интердисциплинарни карактер и постати занимљив за истраживање, како у природним тако и у друштвеним наукама. Као такав, почиње да се примењује у књижевној теорији, истражујући различите варијације модалности у фикцији и начине на које се фикционални светови стварају. Увидевши потенцијал примене концепта могућих светова на књижевну теорију фикције, група аутора (Томас Павел (Thomas Pavel), Лубомир Долежел, Умберто Еко (Umberto Есо), Јури Марголин (Juri Margolin), Мари Лор Рајан (Marie-Laure Ryan) и други) адаптирају теоријску парадигму и појмовни апарат заснован на реинтепретацији Лајбницове идеје, модификујући га на начин који ће им послужити за заснивање новог теоријског дискурса о фикционалности. Применом на проучавање књижевности ова методолошка грана доприноси афирмацији једне комплексне и обједињене теорије фикционалности и омогућује оријентацију ка онтолошком аспекту текстова. Заузимање такве перспективе резултовало је коначним ослобађањем од миметичког начина тумачења, али и могућношћу за проучавање и опис сложенијих онтолошких структура, које пласира књижевност новијег времена.

Као водећу методолошку парадигму за истраживање којим се овај рад бави, изабрали смо теорију фикције Лубомира Долежела, односно теорију могућих светова примењену на проучавање књижевности. Детаљнију елаборацију овог типа фикционалне семантике Долежел је представио у књизи Heterokosmika: Fikcija i mogući svetovi, која ће нам послужити као теоријска основа за каснију примену ове теорије на одабрани корпус. Проучавање фикционалних јединки и њихових идентитета ослониће се у највећој мери на теоријске поставке Јурија Марголина, а целокупну анализу Булатовићевих дела теоријски ћемо поткрепити и радовима Дејвида Луиса, Мари-Лор Рајан, Хилари Даненберг (Hilary Dannenberg), Рут Ронен (Ruth Ronen), Томаса Павела и Снежане Милосављевић Милић. Разматраће се природа и онтолошки статус могућих светова, модални системи фикционалног универзума романа, кодексни и субјективни оператори који детерминишу фундаментална својства светова, логика фикције, природа наративних јединки, виртуелни домени фикције, трансветовни и дијахронијски идентитети јединки и трансдукција књижевних светова са циљем истраживања могућности апликације водећих теорија о могућим световима у књижевности на романескни диптих Миодрага Булатовића. Очекивани резултат усмерен је, најпре, на ревалоризацију Булатовићевог стваралаштва и уочавање оних аспеката његове фикције који нису истражени у досадашњој литератури; издвајање и анализирање различитих типова фикционалних светова и јединки који у њима егзистирају и сагледавање функције и значаја постојања вишеструких светова за основну ауторову интенцију и значења дела. 
2. Фингирано коауторство; метафикцијско подривање аутентизованог света

Означивши „најрадикалније порицање књижевних канона” у токовима српске књижевне прозе (JEREMIĆ 1978: 21), књижевно дело Миодрага Булатовића својом појавом средином 20. века иновира и динамизује дотадашњи модел књижевног стварања и делује као својеврсна инаугурација новог типа прозе послератног периода српске књижевне продукције. Његов почетак везује се за годину 1955, када је објављена Булатовићева прва збирка приповедака Баволи долазе. Ова књига је од почетних критичких промишљања све до данас задржала изузетан статус и неоспориви књижевноисторијски значај, а убрзо потом уследила су и дела Вук и звоно (1958) и Црвени петао лети према небу (1959), која чине (у критици истицану) прву фазу Булатовићевог књижевног рада. Своју гротескно-трагичну стваралачку визију света Булатовић наставља и у другој фази књижевног опуса, допунивши је пакленом визијом свеопштег ратног расапа, датог у романима Херој на магариу (1967) и Pam је био боли (1977). Означивши нову етапу у Булатовићевом стваралаштву, Херој на магариу понудио је ново, радикално виђење ратне теме, сагледане на подлози дотадашње клишетиране и идеолошки сенчене литературе која обрађује ову врсту тематике. Признајући овом роману превратнички значај, критика истиче специфичност булатовићевске визије у којој је ратна тема „лишена херојске и патетичне димензије, а ратно време је показано као најизразитија прилика да се кроз сатиру, карикатуру, демонско ругање и преувеличавање оваплоти човеков пораз у тражењу своје судбине као бића од вредности" (JEREMIĆ 1997: 235-236). Фикционални свет овог романа и његове кључне јединке настављају своју егзистенцију у другом делу романескног диптиха - у роману Pam је био бољи, који фигурира као наставак првог и са њим чини јединствену наративну целину. Однос између ова два романа у контексту наше анализе могућих светова биће сагледан на релацији матичног света и његовог текстуалног сукцеcopa.

У критици је већ поменуто да је принцип паралелизма један од кључних поступака Булатовићевог профилисања пародичне и карневалске слике света у овим делима, који му омогућава да „постојано преноси патетику теме на план гротескног и фантастичног преображавања" (JEREMIĆ 1997: 237-238), односно да успостави специфичан систем nовезаних светова, као „наративну парадигму у новом кључу” (PIJANOVIĆ 2001: 158). Поступак удвајања и паралелног структурирања света очитава се на готово свим нивоима поменутих романа: на нивоу наративне 
стратегије, алетичке, деонтичке и епистемичке структуре света ${ }^{2}$, реалног/виртуелног раслојавања текстуалног корпуса, трансдукције фикционалних светова и идентитета. Због запажене фабуларне, семантичке и наративне слојевитости овај романескни диптих представља погодно тло за анализу различитих типова могућих светова, којима аутор успева да уобличи своју аутентичну уметничку замисао.

Као потврда поменутог принципа паралелизма, специфично наративно уобличење романа Херој на магариу настаје проблематизацијом приповедачке позиције, односно удвајањем наративних перспектива. Стваралачко поигравање са главном приповедачком тачком гледишта резултује њеним подривањем и поништењем, путем накнадне идентификације ауторске инстанце са инстанцом једне од фикционалних јединки света - Антонијом Педутом. Представљањем Педута као писца рукописа „Време срама”, који, како сазнајемо у делу, постоји као прото-текст Булатовићевог романа, литерарна мистификација дејствује као процес конфигурације основног, eо ipso аутентизованог света и његовог паралелног, метанаративног дискурса. На тај начин, наративни потенцијали текста истовремено конструишу фикционални свет и причу о његовом настанку, чиме се аутентизација ${ }^{3}$ поништава „огољавањем” приповедног

2 Подлогу за изучавање модалитета Долежел је нашао у теорији делања Г. Х. фон Рихта (Georg Henrik von Wright), а у оквирима наратолошких истраживања надовезао се на Владимира Пропа (Владимир Яковлевич Пропп) и А. Ж. Гремаса (Algirdas Julien Greimas). Приликом формирања фикционалних светова, могу се издвојити четири модална система, од којих сваки оперише различитим модалитетима и ограничењима. Модалне структуре, при томе, бивају детерминисане кодексним и субјективним операторима. Долежел издваја следеће модалитете: алетички - могућност, немогућност и нужност, деонтички - забрана, обавеза, дозвола , аксиолошки- индифирентно, добро, лоше, епистемички - знање, незнање, уверења (2008: 124-142). Елементарна поставка подразумевала би стављање једног модалног система као доминантног, чиме се генерише тзв. модално хомогени свет. Спајање двају домена који су детерминисани опречним модалним ограничењима у један фикционални свет твори модално хетерегоне или двоструке светове (2008: 139).

3 Будући да су фикционални текстови могући светови којима је додељена фикционална егзистенција, требало би се позабавити питањем ко/шта додељује егзистенцију фикционалним ентитетима. Долежелов одговор на ово питање представљен је тзв. функцијом аутентизације (2008: 154-176), објашњеном као моћ текста која вреднује текстуалне изразе као истините или нестините судове, и истовремено ограничава опсег интензионалне функције. Аутентизација располаже различитим степенима ауторитета, кроз различите наративне гласове; виша позиција у наративној хијерархији доноси већи степен ауторитета. Ентитети уведени дискурсом приповедача сматрају се eo ipso аутентичним, образујући чињенични домен фикционалног света, док ентитети уведени дискурсом фикционалних особа немају нужно такав статус. Међу могућностима подривања аутентизације, Долежел издваја сказ (самопоништавање аутентизације иронијом), метафикцију (огољавање приповедног поступка), и конструкцију немогућих светова (семантичка стратегија урушавања аутентизације) увођењем противречности у 
поступка.

Поменути наслов „Време срама” фигурира на равни фикционалног света романа, али је приликом првобитног објављивања дела у часопису био наведен и као стварни део наслова. На двојништво стварног и фиктивног ауторства указује и сам Булатовић у интервјуу поводом објављивања немачког превода Хероја на магарцу 1965. године: „Мој двојник, италијански мајор Антонио Педуто, истовремено са мном пише роман о истим личностима. Мој роман се зове Херој на магариу, а његов Време срамоте (...)" (према: ŠUKALO 2002: 177). У осталим верзијама романа, међутим, овај наслов се изоставља.

Поступак фингирања ауторства уочава се на првим страницама Хероја на магариу, у обећању мајора Антонија Педута да ће у некој од следећих књига пуковнику Алегретију посветити више пажње: „Obožavam te, reče Antonio (...) Divno nas prezentiraš i neverovatno uvećavaš našu zdravu, našu herojsku i užasnu naciju. I budi siguran da ću ti u jednoj od mojih budućih knjiga posvetiti više poglavlja" (BULATOVIĆ 1967: 22). Конкретније назнаке о удвајању ауторских перспектива запажамо у једном од разговора генерала Беста и мајора Педута. Њихов дијалог недвосмислено открива двострукти мајоров идентитет, представљајући га као писца књиге о власнику крчме и представнику месног отпора, Грубану Малићу, односно, као протописца самог романа Херој на магариу:

„Opisujem ga (...) Moji zapisi o njemu već iznose pet stotina stranica, reče tiho major Peduto. A imam utisak da bih taj motiv mogao obrađivati do kraja života. (...) Ono što sam zapisao poslednjih godina niko neće ni smeti, ni hteti da publikuje, reče major Peduto sa smeškom nekoga ko se miri čak i sa paklom. Jer je reč o bitnim problemima. Uostalom, malopre sam pokušao da vam objasnim svoja načela i teme: čovek, slava i pornografija" (1967: 293).

Педутови аутопоетички искази долазе до изражаја на више различитих места у роману, а најексплицитније су дати у његовим мисаоним или вербалним обраћањима ликовима из окружења који су, како сазнајемо из метанаративног дискурса, литерарно пројектовани у његов рукопис:

„mali moj Calabrese, ti i ne znaš da postaješ večit. Upravo onog trenutka, dok plačeš a ja se ljuljam na umornim i dugim nogama, rešio sam o tebi da pišem. I tamo ćeš, u toj verovatno smešnoj knjizi, šakom i rukavom razmazivati suze i čeznuti za smenom i jednom prljavom a nedostižnom kurvom. Ali da bi moja knjiga uspela, niko neće hteti da te odmeni. (...) Nestaneš li odatle pre vremena, odoše s vetrom, prašinom i svetlošću i moja skaradna knjiga, i moji simboli, i sva moja setna pakost." (BULATOVIĆ 1967: 67).

фикционални свет (2008: 168-176). 
Мајорова тачка гледишта на овај начин брише границе између стварног света текста и приче о његовој конструкцији. Јединке фикционалног универзума ${ }^{4}$ романа егзистирају на два нивоа, односно један исти фикционални ентитет појављује се у два егзистенцијална модела.

Централни лик фикционалне и метафикцијске равни јесте Грубан Малић, који, по речима Педута „припада књижевности, историји, легенди”. Педутова аутопоетичка свест креира коментаторски дискурс о књижевним устројствима романескних ликова (најчешће Малићевог лика), али и о сопственим стваралачким намерама при поступку литерарног уобличавања фабуларног предлошка. Идентитетске релације додатно се усложњавају Педутовом идентификацијом са Грубаном Малићем, у којем мајор проналази свој литерарни прототип, али и своју „најлепшу метафору”. Тако се Грубан Малић открива као „покретач и исходиште гротескног раја нове идеологије”, „механичка рука” протописца којом унижава тирански свет, метафора „која својим тропичним смислом покрива бизарну креативност света у расулу”, и, у крајњој линији, као Педутов двојник (PIJANOVIĆ 2001: 174-175).

Суперпонирањем Педутових различитих егзистирајућих статуса на равни стварног света текста, мајор се појављује не само као лик и протописац приче романа, већ и као главни коментатор и тумач поменутог рукописа, а већ истакнута двојничка релација добија још једног, трећег члана низа на линији аутор - протописаи/приповедач - јунак - Грубана Малића. У спрези приче и њеног метапоетичког коментара, Педуто као њен наративни субјект успева да се хуморно и цинично поигра са сопственим стваралачким процесом, посредно обликујући роман о роману. До потпуне идентификације Педута и Малића долази на крају дела:

„Meni, večitom vojniku i ukrotitelju kornjača i zvezda, od danas je drugo ime Gruban. (...) Dakle, Antonio - Gruban, već trideset i osam godina star i, zahvaljujući Malićevoj zaštiti i pomoći već general, admiral, nosilac svih medalja (...) Nos bogat, nekad rimski, ali odnedavno namerno prelomljen, kako bi što više ličio na Grubanov. (...) Grudi hrabre, isturene, baš kao Malićeve" (BULATOVIĆ 1967: 433-434).

4 У познатој научној студији „еdinke u narativnim svetovima: jedna ontološka perspektiva”, Јури Марголин образлаже своје настојање да формулише једну комплементарну теорију књижевних ликова посматраних као јединке у нестварним, односно фикционалним световима. Појам нестварне јединке Марголин дефинише на следећи начин: „Jedinka je pripadnik neke/nekih obasti ovog mogućeg sveta, i ona se u njoj/njima može na jedinstveni način identifikovati, locirati u nekom prostorno-vremenskom regionu, i mogu joj se pridavati raznovrsna fizička i umna svojstva i odnosi, uključujući tu društvena, govorna, epistemološka, kognitivna, emotivna, voljna i percepcijska. Jedinka može posedovati unutarnja stanja, znanje i skupove uverenja, karakteristike, namere, želje, raspoloženja, sećanja i stavove, tj. unutrašnjost ili svojstvo ličnosti” (MARGOLIN 1997: 88). 
Двојништво поприма облик потпуне идентификације на краjy, чином стапања биографских чињеница, иако, како запажа Младен Шукало, језички аспект остаје „основни елемент разграничавања свих видова удвајања” између мајора и Грубана, као „лица и наличја Једног” (ŠUKALO 2002: 166). Комплексна приповедачка стратегија тако обједињује две главне нараторске позиције: спољну, ауторску, свезналачку, која није део нити субјект фабуларног тока, и унутарњу, Педутову, која је његов константни учесник. На тај начин се поменути принцип паралелизма огледа и у наративној поставци романа, непрестаним алтернирањем приповедачких светова. Крајње поистовећивање „унутарњег” приповедача са ликом којег је сам створио затвара приповедачки круг „очуђавањем и инверзијом" (PIJANOVIĆ 2001: 229), чему сведочи и последња сцена романа, у којој се Антонио гуши „Малићевим сузама”.

Паралелизам наративних и фикционалних светова присутан је и у роману Pam је био бољи, али са другачијим, измењеним наративним обрасцом. Сукцесија матичног света текста из романа Херој на магариу обележена је измештањем истих главних ликова из црногорског простора и додавањем неких нових јединки, као и променом просторне топографије у наставку романескне приче. Промена обрасца наративне реплике у роману Pam је био бољи очекивани је след дешавања из прве књиге, будући да укључивање генерала Бесте у бјелопољска дешавања од почетка бива праћено и забележено камером. Такође, Антонио Педуто већ при крају прве књиге најављује да ће Малић „проклијати са целулоида и опет угрозити човечанство" (BULATOVIĆ 1967: 427). Наспрам Педутовог паралелелног метапоетичког дискурса у Хероју на магариу, у другом роману носиоци концепта „филма без сценарија” постају сценариста Сергеј Иванович и редитељ Жорж Бонфу: „Naš film mora uspeti, Georges! (...) Naš film će biti epopeja, pravo remek-delo, neka vrsta poeme o ljudima koji priznaju čistu emociju, sve što je uzvišeno i nadrealno, dušu! Scenarija neće biti! Mešaćemo i dalje život i celuloid, krv i hemiju! I film će se napraviti sam! (BULATOVIĆ 1986: 105) Замисао о филму без сценарија додатно поткрепљује Жорж, идејом да, пратећи кретање Педутове дружине кроз Италију, Француску, Шпанију, Немачку и Данску, овековечи њихове походе филмом „који се сам ствара”. Тако конципиран филм, како наводи Пијановић, постаје „непосредна реплика животу, постаје прича у причи Булатовићевог романа, његово дупло дно, подлога и његова грађа" (2001: 242). Занимљиво тумачење Булатовићеве стратегије наративног удвајања дао је Младен Шукало, истичући да метафикционалне подлоге ових романа иницирају коначну „смрт аутора и ауторства”, односно обесмишљавање и смрт литературе уопште: „Живљење литературе као паралелног свијета требало би да означава предуслове за њено ново рађање” (2002: 
173).

Фимска епопеја о бившим и пораженим ратницима који верују у то да је „рат био бољи” случајно отпочиње покушајем самоубиства Карла Шлотерера, што представља један од првих кадрова „филма без сценарија”. Укрштањем других фабуларних токова, спој режисера и сценаристе са Грубаном Малићем, Педутом, Боначом и осталима изнедриће идеју о стварању филмске лакрдије о новом освајању Запада, чије су главне улоге гротескни кловнови модерног постхеројског доба: „Ići ćemo ispred njih, od trga do trga, ako bude trebalo - i od grada do grada! Plaćaćemo statiste, narod, da se povlači, da beži, dok oni budu napredovali! Zauzimaće Zapad, mi ćemo s kamerom za njima! Biće to najzanimljivije zauzimanje ovog prokletog kontitenta..." (BULATOVIĆ 1986: 129). Инверзивни, гротескни поредак ствари дејствује и овде - режирање и монтирање живота зарад филмског овековечења симулираних похода на Запад резултује оснивањем нове, аспурдне и лажне стварности, која задире у стварни свет текста. Филмска илузија почиње да подрива аутентизовани свет романа онда када границе између њих почињу да се бришу. Тако двослојна структура фикционалног света губи чврсте темеље и оставља читаоца у недоумици о природи приказане фикционалне стварности.

Трећи вид метафикционалног преокрета инициран је променом уметничког кода у другом роману, у тренутку када филм, као наративни дупликат приче, бива замењен театрализацијом циркуске тачке која носи назив самог дела - Pam је био боли. Слабљење аутентизације стварног света постиже се кабаретском представом у којој главне улоге тумаче управо режисер и сценариста филма. Однос између стварног наслова дела и фикционалног наслова циркуске тачке поново нарушава границе фикције и стварности и готово реплицира однос Педутовог рукописа и првог романа - Хероја на магариу. Иванович и Бонефу, заједно са Шлотерером и Педутом постају чланови импровизованог позоришта апсурда, у којем не глуме, већ, практично представљају себе саме, исповедајући личну трагику на гротескној и натуралистичкој циркуској сцени. Устаљено ауторово онеобичавање проседеа и иронијско поигравање фикционализацијом и наративним поступком потврђује се у тренутку када циркуски кловнови постану засићени расулом мирнодопске стварности. Незадовољни улогом коју им је доделио „живот, циркус и историја” и згрожени Западом, тужне маске мирнодопског хаоса решавају се на „бекство у даљину", којем се придружује и публика. Тако се циркус у својој крајњој тачки преноси са импровизоване сцене на улицу, а симболичким пробијањем закључаних врата дворане театар апсурда бива инфилтриран у сам живот, пробијајући баријере између глумаца и публике, симулације и стварности, текста и његове реплике. Визија о бегу у пустош која 
„једина може испунити празнину њихових пропалих душа” заправо на симболичком фону догађаја представља бекство од сопствених бесмислених живота и себе самих, будући да глумци беже са сцене на којој исповедају ништа друго, до своју истиниту и реалну личну судбину.

3. Деонтички параметри - марионетизација појединца у ратном и мирнодопском циркусу

Деонтичка структура Булатовићевог фикционалног универзума у романима Херој на магариу и Рат је био бољи организована је на опозицијама дозвола/забрана/обавеза, чији је примарни модулатор рат, односно институције које оваплоћују репресивни друштвени домен Булатовићевих романа. Репертоар мотивационих поступака које писац користи при конструисању фикционалних светова у овим романима има своју основу у поставкама реалистичке мотивације, којом Булатовић уобличава ратну стварности у Бијелом Пољу 1943. године, дане италијанске окупације црногорске варошице који претходе капитулацији Италије у првом роману, односно послератно стање у Европи дато у другом делу романескног диптиха. Првопостављени реалистички оквир се, међутим, у складу са ауторовим стваралачким интенцијама убрзо подрива, док рат као доминанти модулатор збивања остаје у оба романа главни фон на којем се реализује визија о свеопштем расулу и персифлажи европског друштва.

Друштвено устројство романа Херој на магариу доноси сусрет и портрет двају народа (Италијана и Црногораца) и двеју култура у „прљавим временима", како истиче сам Булатовић (према ŠUKALO 2002: 182). У другом роману тај приказ се проширује сликама осталих европских народа. Ипак, доминантне представе ових нација и њихови главни представници су као фикционалне јединке детерминисани мрежом ратног/ поратног друштвеног система, а друштвено и приватно деловање свих јединки ограничено је глобалним ограничењима надиндивидуалног ратног кодекса. Модалитете деонтичког система у делу регулише институција војске, која управља друштвеним деловањем у виду експлицитно прописаних норми, али и деловањем јединки којима деонтички модалитети обавезе или забране сужавају опсег дозвољеног и регулишу кретање и акцију. Делања житеља стварног света текста директно су зависна од система забрана и дозвола прописаних од стране војног система обају народа, због чега су јединке непрестано ускраћене за поступање по сопственом нахођењу. Ипак, будући да се ради о италијанској окупацији црногорске варошице, врховни деонтички ауторитет овде припада италијанском фашистичком „новом поретку” који је конципиран као пројекат „ослобођене нације” и „свеопштег препорода” и из њихове визуре пред- 
ставља не само национални, већ цивилизацијски чин. Односи између друштвено наметнутих обавеза и забрана и субјективних жеља ликова у овом роману варијају од конформизма до побуне, мада је заједничка црта већине ликова незадовољство, промашеност и пораженост целокупним стањем ратног хаоса и бесмисла. Другим речима, статус јединки фикционалног универзума у роману превасходно је дефинисан позицијом коју та јединка заузима у ратној атмосфери мале црногорске варошице.

Конформистички однос према деонтичком устројству света романа поседују јединке које се налазе на самом врху хијерархизованог војног система - као најистакнутији међу њима појављују се пуковник Алегрети и генерал Беста, а у исту групу можемо сврстати и капетане Брамбилу, Басу, Тоцију, Кацодуру. Од црногорских становника, најмању колизију кодексног и субјективног деонтичког домена налазимо код морално најискваренијих припадника црногорског народа - главног месног шпијуна Мустафе Агића, али и код Марике, која љубавним животом међу италијанским војницима у потпуности преузима италијанску визуру, идентификујући се са својим љубавницима. Већину италијанских војника, међутим, у роману видимо као принуђене поштоваоце установљеног система норми и обавеза, који упркос очигледном сукобу између деонтичких кодекса и властитих тежњи, остају дисциплиновани унутар прескриптивних хијерархијских матрица. Један од њих је војник Салваторе Паолоне, „стражар без смене”, који све време у роману дежура поред тенка и не добија замену. Притисак деонтичког модалитета обавезе навешће војника да се у фантастичној слици нарастања пушке као стабла узвере уз исту и оконча сопствени живот. И остали војници који су лишени тежње за било каквим револуционарним деловањем и побуном, улазе у процес колективне марионетизације и постају пуки објекти војне машинерије. Због наметнуте војне обавезе коју издаје капетан Брамбила и војник Пиетро Портулу страдаће у загушљивој и крвавој Рашковој тамници. Трагични исход ће у појединим случајевима доћи и као узрок првобитног неизвршавања обавезе - попут страдања Аугуста Наполитана од стране црнокошуљаша, припадника фашистичке паравојске, због одбијања да по њиховом налогу пева антикомунистичке песме. Оба случаја, и испуњавање и кршење модалитета деонтичке обавезе доводе италијанске војнике до трагичног исхода. На значењском нивоу дела то уобличава идеју о бесмислу и апсурдности ратне репресије, која по законима неизбежне ратне „механике” разорно делује на све јединке фикционалног света.

С обзиром на то да врховни деонтички регулатив у роману Херој на магариу представља окупаторска италијанска војска и њени спроводитељи, деонтичко модално несагласје, осим поменутог раскола изме- 
ђу кодексног и индивидуалног домена унутар италијанског колектива, обухвата још један надиндивидуални кодекс - црногорски. На подлози тог модалног несагласја гради се и слика црногорских војника, претежно дата из италијанске перспективе, у којој се Црногорци представљају као стални деонтички преступници, кршиоци прокламованих забрана, што је случај у роману Pam је био бољи, где се та слика даје углавном из визуpe Немаца: „Prokleta da je Crna gora i proklet da je i onaj ko je takvu stvorio i tamo ostavio! Cela naša divizija bila je angažovana, ali se Crnogorci nisu predavali. Naprotiv! Nasrtali su, kosili su nam najbolje momke! (...) Strašan nakot!" (BULATOVIĆ 1986: 59-60) У сличном тону се и у Хероју на магарцу истиче како Црногорци „манијачки нападају”, „лудо гину”, „насрћу као Јапанци” и „не броје лешеве” (према ŠUKALO 2002: 200).

Сукоб кодексног и личног најснажније долази до изражаја и у случају најочигледнијег деонтичког странца у Хероју на магариу - Грубана Малића. Заправо, цео роман се може читати као парадигматична прича о деонтичком/аксиолошком/епистемичком странцу, који се, у контексту деонтичког маркирања, ослобађа владајућег кодекса и руководи се властитим тежњама и циљевима. У првом роману, тај порив се појављује као жеља за придруживањем непостојећој црногорској дивизији, са циљем испуњавања херојског и револуционарног кода у комунистичком систему традиционалне балканске ратничке културе. У том погледу, Грубан Малић се појављује као сугестија деонтичке и аксиолошке другости, који кршећи деонтички модалитет забране жели да испуни херојску обавезу оног етничког и културног модела коме заправо и припада. У помереној, илузивној оптици, Булатовићев витез тамног лика верује у постојање Петсто прве црногорске армије, у један непостојећи свет уобличен идеолошким заблудама, који ће надаље бити лажан мотивациони подстрек његовим акцијама и изазовима.

На Малићеву изопштеност из нормиране деонтичке структуре романа симболично се указује већ у сцени карневалске церемоније поводом дочека генерала, у којој Малић одудара од „свеопштег белила” окречене вароши, са кантом црвене боје поред себе. Деонтичка опозиција представљена у виду односа између беле и црвене боје на симболичкој вертикали подразумева однос између присталица и противника врховног деонтичког ауторитета. У непрестаној жељи да постане херој и задобије поштовање и славу, Грубан уображава да је личност од велике важности у касаби и истакнути противник окупационе војске. Мотивисан таквим тежњама, његови даљи подухвати своде се на низ деонтичких прекршаја, који би навели Италијане да га потраже и ухапсе. Почевши од остављања провокативних порука на вратима своје радње: „NEĆU VIŠE DA RADIM ZA „OKUPATORA”. RADNJU ZATVARAM IZ „POLITIČKIH” RAZLOGA” 
(BULATOVIĆ 1967: 218), „OVO JE RADNJA VELIKOG KOMUNISTIČKOG KRIMINALCA KOG TREBA U LOGOR PROTERATI” (1967: 246-247), све до намерног показивања револвера и бомбе, Малић очајнички прижељкује реакцију италијанске војске и конфронтацију којом би се прокламовао као херој своје вароши. У тоталном одступању од логике приче о деонтичком паду, која подразумева казну након нарушавања деонтичких норми, Малић у виду потпуно изневереног очекивања не добија жељену реакцију, па прижељкивана казна изостаје:

„Malić se kiselo iskezi. Jer se više niko nije zadržavao pred njegovim vratima. Vojnici su pokušavali da uđu, zvali ga po imenu, a onda sa stepenica silazili na kaldrmu. Preletali su očima preko velikog lista i reči i, ne nalazeći u njima ništa neobično, žurili da što pre stignu do rakije, devojaka i pesme" (1967: 231); „Čitali su crvene rečenice i nervozno se smeškali: jedino je bio razdragan i srećan pukovnik - hteo je da baci dete i zagrli čoveka na kolenima, da rastera pijanu rulju koja se uvećavala i da grlić boce prinese krvavim i zapečenim Malićevim usnama" (1967: 248).

Кулминација Грубановог кршења забрана долази на крају првог романа, када као последњи покушај иницирања хапшења решава да побегне и прескочи бодљикаву жицу која ограђује окупирану црногорску касабу. Циничан и ругајући Булатовићев подсмех упућен сопственом антихероју учиниће да жељени одговор власти поново изостане, ускраћујући га за херојски чин и страхопоштовање којима непрестано тежи. Насупрот очекиваној казни за прекршај постављене забране, Италија му, по речима Антонија Педута, „опрашта живот” и честита чин у штабу непостојеће црногорске армије, пуштајући га да слободно прође испод подигнуте рампе. Изостављене реакције власти и неочекивани деонтички чин дозволе на крају у потпуности детронизују лажног хероја, онемогућују га да се потврди као званични противник окупаторима и дејствују као суноврат једне идеалистичке визије, што је у складу са општом тенденцијом писца да рат представи из инверзивне, пародичне и карневалске визуре.

Будући да војска, као институција са строгом деонтичком структуром, намеће надиндивидуална ограничења која угрожавају интенционалност и аутономију делања ликова Булатовићевих фикционалних светова, кључни мотивациони фактор у роману Херој на магариу представља моћ, којом је контролисано и друштвено и приватно делање фикционалних јединки. Моћ се овде појављује као мотивациони темељ репресивног политичко-војног система спроведеног од стране Италијана, односно као круцијални фактор који регулише еротску активност на плану приватне интерације јединки. Заправо, еротика и порнографија, као важни мотиви у Булатовићевом прозном диптиху, функционишу не 
само као средство приказа моралне и свеопште деструкције вредности у атмосфери ратног хаоса, већ и као својеврсни облик анархизма, тј. једини вид слободног делања које измиче строгим деонтичким модалитетима обавезе/забране/дозволе. Због тога оба романа обилују еротским и натуралистичким описима, који дословно отелотворују гротескно, односно карневалско материјално-телесно начело живота. Демонстрација моћи на приватном плану путем еротских баханалија нарочито је истакнута код ликова који по функцији имају водеће положаје у друштву, попут еротомана Алегретија или Бесте. Ништа мање то није изражено и међу обичним војницима, који, иако немоћни у сфери јавног делања, настоје да нагон за поседовањем моћи или слободе задовоље у приватном домену, у виду непрестаног сексуалног пражњења и сексуалне принуде. Деонтички параметри забране и обавезе тако стимулишу еротску активност ликова на приватном плану, на којем сексуални чин, одређен искључиво фактором нагона, постаје најобичнији сексуални praxis. У свету колективних, јавних силовања, која откривају дехуманизовано и монструозно наличје света, са свакодневним призорима оргијања и еротског пражњења, духовност је замењена материјално-телесним принципом живота које на карикатуралан и гротескни начин приказује неуспелу „потрагу за вештачким рајем" (PIJANOVIĆ 2001: 186). Слично запажање износи и Лидија Томић која еротику у роману Pam је био бољи превасходно види као средство приказивања гротескних ситуација духа, физичког испољавања власти, мегаломаније и заумности, али и као „карикатуру агресије, насиља и илузије” (ТОМIĆ 1998: 41): „Еротиком се, стога, као физичким дејством, Булатовић противи лимиту дозвољеног” (1998: 41).

Слика расула италијанске војске, којом завршава први, а отпочиње други роман Булатовићевог диптиха, доноси промену деонтичке структуре у роману Pam је био бољи. Први део књиге, који прати спровођење Антонија Педута и остале групе већ познатих ликова у немачки логор, поседује деонтички систем сличан првом роману, у којем су модалитети одређени ратном ситуацијом. Овде се, међутим, ради о немачкој војсци која преузима функцију главног деонтичког ауторитета, док Италијани мењају свој колективни деонтички статус и од некадашњих окупатора постају заробљеници Немаца. На тај начин, фабуларно језгро првог дела романа Pam је био бољи заправо генерише причу о колективном/појединачном деонтичком паду, будући да сви некадашњи ликови мењају своју позицију у првобитној констелацији актера - тако генерали Беста и Алегрети бивају детронизовани, гротескно исмејани и смештени са свим осталим затвореницима у немачки камион. Премисе овог деонтичког система прати сенка нацистичке идеологије, чији је главни извршилац пуковник Шлотерер. Деонтички модалитети примарно контро- 
лисани немачком војном идеологијом не односе се само на затворенике, већ и на саме немачке војнике, чија је делатност ограничена репресијом њиховог војног система. Поштовање строгих деонтичких норми најексплицитније се очитава у сцени у којој Шлотерер тера своје официре да лају како би пробудили заспалу сову. Осим што демонстрира дициплину и послушност немачких војника, симболика ове слике, како тумачи Младен Шукало, „предсказује судбину самог Шлотерера, али и свих Нијемаца у рату који само што се није окончао” (ŠUKALO 2002: 207).

4. Иронизација и инверзија аксиолошког света; епистемичка заблуда витеза тужног лика

Структурирање аксиолошког света у роману Херој на магариу успоставило је две супротно кодиране колективне аксиологије: италијанску (окупаторску) и црногорску. Живот и интеракција ове две нације у роману одвија се у систему кодексног аксиолошког несклада, али се аксиолошка структура додатно усложњава колизијом надиндивидуалних и индивидуалних аксиолошких тежњи јединки, као и примарном тенденцијом дела да релативизује све системе вредности који служе као подлога догађајима у фикционалном свету Булатовићевих романа. Проблематизујући тему рата и поразног деловања идеологије новог поретка на његове учеснике, Булатовић најпре активира неколико традиционалних аксиолошких образаца који ће у оба романа претрпети значајне иронијске интервенције и бити подривени, отварајући простор за успостављање потпуно другачије аксиолошке матрице. Инверзивна аксиологија у овим делима настаје као резултат разградње традиционалних аксилошких образаца и култова успостављених колективном свешћу. Херојски и револуционарни модел света, а са њиме и системи вредности које ови модели носе са собом, у Булатовићевој карневалској обради доживљавају потпуну разградњу. Рат приказан као морални распад и посрнуће у пишчевој карневалској имагинацији разара официјелну ратну идеологију и херојску патетику који фигурирају као главна аксиолошка подлога романескних збивања. Инверзија разноликих вредносних система тако постаје кључни моделативни поступак свих дешавања у романима, најчешће предочених у виду јавних скандала, ексцеса, карневализованих церемонија и свечаности. Педутова карневалска и иронијска приповедачка свест генерише свет у тоталној деструкцији, настојећи да се наруга моралној трулежи људи који (об)ухваћени трагичним ратним механизмима постају марионете у рукама историје.

Први вид иронизације званичног аксиолошког обрасца извршен је разарањем канонских представа о херојима и освајачима, који у констелацији актера заузимају сам врх друштвеног хијерархијског систе- 
ма. Приказом италијанске и немачке војске, моделовањем појединачних фикцоналних егзистенција које постају колатералне штете ратног механизма, Булатовић најпре разара херојску и освајачку аксиолошку парадигму, која представља темељ лажног „ослободилачког пројекта”. У Хероју на магариу је поступком детронизације обухваћена најпре италијанска војска, односно италијански војници и њихови предводници, који, скрајнути и изопштени из свог цивилизацијског простора покушавају да свом боравку у малој црногорској варошици врате изгубљени смисао, препуштајући се нехеројским облицима понашања и разним еротским баханалијама. Док се код главних предводника италијанске војске пародијом херојског и освајачког кода заправо подрива аксиологија фашистичких идеја, коју само привидно интериоризују, већина италијанских војника од почетка иступа са свешћу о поразности и нехуманости владајуће идеологије, што резултује потпуном девастацијом и разарањем фашистичких идеолошких и вредносних стремљења: „О, kakav sram! (...) Kakav pad! Urlao je, dok su mu suze navirale: „Pepino, zar ne vidiš da je poraz potpun, da niko više nije čist?!” (...) Pobednici na kurvama! Već! Heroji i oslobodioci su tako za sva vremena ismejani i osramoćeni!" (BULATOVIĆ 1986: 21-22).

Лик пуковника Алегретија најистакнутији је пример подривања спољне, наметнуте аксиологије фашистичког покрета. Иза лажних патриотских и идеолошких декларација и поштапалица које Алегрети јавно пропагира, крије се егоизам и еротска пожуда која мотивише сва његова кретања. Посвећеност фашистичким идејама се тако открива као привид, а инвертовани аксиолошки образац у свом наличју открива све нехеројске пориве и сладострашће главних спроводилаца фашистичког система. У пародијском обрту, Алегрети, који на симболичком фону збивања представља свог идејног вођу и појављује се као симболички представник фашистичке Италије, своје време у окупираној вароши проводи у различитим љубавним аферама са црногорским женама и, како подсмешљиво истиче Педуто, интензивно ради на умножавању ратне копилади и увећању њихове „херојске и ужасне нације”. Иронијско обеснажење кодексне аксилогије непрестано својим ругалачким коментарима потцртава Педуто, истичући чињеницу да се „гонореја брже шири од фашистичке идеологије”. Карневалским свргавањем главног представника италијанске војске Булатовић успева да унизи лажну ратничку романтику и покаже право лице званичног аксилошког система - гротескно и трагикомично. Алегретијева немоћ, инфериорност и плашљивост откривају се градативно у низу ситуација, попут немогућности да узјаше коња, или панике која га обузима док лети авионом изнад Бијелог Поља. На лажну посвећеност колективној идеологији указује и Марика, када описује свој доживљај Италијана: „Vama je sve za porugu, sve, počev od sopstvene 
ideologije, borbe, svinje!” (BULATOVIĆ 1967: 204). Профилисање лика генерала Бесте, чија је највећа слабост „хватање лептира” такође сведочи о гротексно-карневалској обради ликова и правим аксиолошким тежњама Италијана, сакривеним иза празних и бесмислених фашистичких парола. И уопште, карневалски интонирана колективна слика Италијана који „само пију и оргијају” доприноси општој тенденцији дела да разоткрије амбивалентне валере званичне аксиолошке матрице коју принудно усваја разорена италијанска солдатеска.

Централна личност оскрнављене херојске патетике је Грубан Малић, трагикомични Булатовићев антихерој, чији животни пут од црноберзијанца и власника бордела до револуцинара, праведника и месије дејствује као подсмех револуционарно-херојској културној парадигми. Первертирање херојског модела започиње његовим „копиланским” пореклом, амблематичним именом и нехеројским изгледом, а наставља се понашањем и делањем којим писац, али и протописац Педуто, срозава све оне аксиолошке обрасце активиране у позадини ратне тематике и реалног историјско-социјалног миљеа на који се дело ослања. Лик хероја на магарцу јавља се у Булатовићевом опусу као пародија револуцинара:

„karikatura (...) čoveka kome cilj služi kao put da prevaziđe vlastitu ništavnost, i on ne može nigde da se uklopi i lebdi poput prazne pahulje, suvišan, jadan, groteskan, bolan u najdubljoj osnovi bića. (...) Otuda je on zaista nešto kao parodija revolucinara, fikcijska grimasa čoveka iz postrevolucinarnog vremena koji nema iluzija i zato stvara donkihotovsku figuru (...) sa smešnom i tragičnom maskom bolne marionete." (TOMIĆ 2005: 135)

Гротескно моделовање црногорског homo heroicusa у потпуности потврђује претензију ревидирања херојског мита које се остварује заменом свега онога што би требало бити узвишено, јуначко и величанствено ниским, јадним и кловновским. Булатовићев кловн модерног доба настао у луцидној и помереној уобразиљи пијаног мајора Антонија Педута то у више наврата потврђује. Ауторова имплицитна полемика са традиционалним моделом ратног и херојског романа резултовала је, на једној страни, лажном италијанском реториком иза које се крије крајњи дефетизам и трагика ратног расапа, а на другој страни трагикомичном персифлажом и карикирањем витешког кода у лику Грубана Малића.

Паралелизам трагичног и комичног у профилисању Малићевог лика омогућио је да се херој на магарцу експонира као „groteskna parodija epskog junaka i epske veličine uopšte" (2005: 141). Вођен својим идеолошким лудилом колико и жељом да буде поштован и цењењен у заједници којој припада, Малић својим инцидентним понашањем унижава племенски дух и морал, а његови изазови и подухвати на путу до стицања жеље- 
не вредности готово увек добијају фарсичан обрт. Малићева „револуционарна активност” своди се на дељење комунистичких летака, покушаје конфронтирања са италијанским официрима, или трагикомично застрашивање оружјем. Декомпоновање јуначког мита наставља се и након његовог изласка из ограђене вароши, где своје „борбене” дане проводи у љубавним доживљајима са женама, да бисмо га на крају романа видели са туђом војничком одећом на себи, са ордењем из ратова украденим од других црногорских војника, у друштву удовица које је у међувремену оплодио. Тиме се, заправо, традиционалне аксиолошке формуле ратничке балканске културе уводе у неку врсту минус поступка, чиме се оно јуначко време, толико пута раније описивано у класичним ратним романима, заиста преводи у време срама.

Комично, међутим, гравитира ка трагичном у сваком Малићевом пропалом покушају да добије жељену реакцију Италијана, што га сваки пут онемогућује да лични комплекс безвредности коначно компензује учешћем у светској револуцији. Раскорак очекиваног и добијеног све више продубљује његов пад и води га до спознаје сопствене ништавности, што профилише трагикомичну кловновску фигуру насталу у процесу гротескне синтезе тривијалног и узвишеног. Овако конципиран профил антијунака додатно се моделује активирањем епистемичких оператора знања, незнања и уверења, чиме се фикционални универзум романа у епистемичком контексту обликује као спој фикционалне стварности и лажног света Грубанових уверења и заблуда. Нека врста илузивне, померене и идеолошки сенчене перспективе чини да субјективни епистемички домен Грубана Малића представља мотивациону основу његовог делања, чија је почетна тачка заблуда о постојању Петсто прве црногорске армије. Грубан Малић се тако испољава као лик који у крајњој линији постаје жртва сопствене епистемичке заблуде, односно епистемички странац кога ће аутор искористити за спровођење пародије лажних идеала. Грубанова заблуда, са друге стране, оснажује се обманом од стране лопова, који се у склопу једног од симулираних наратива ${ }^{5}$ романа представљају као извештачи делагације која заправо ни не постоји, како би од Грубана изнудили новац:

„Но, доскочили смо му. Ми му подмећемо војни материјал, пушке, пиштоље, пушкомитраљезе, муницију, бомбе, шлемове, шаторе, који су на великој цени код народа, робу уопште. Он купује све редом и шаље

5 Симулирани наративи (по типологији виртуелних наратива Снежане Милосављевић Милић) односе се на домен деловања ликова који приликом претварања, лагања, или глуме свесно стварају привид реалног. На тај начин, ликови играју одрећене улоге, при чему се успоставља јасна граница између онога што је истинито и симулирано. Овај тип наратива разликује се од других по томе што бива реализован на нивоу света приче, али је заправо њена лажна верзија (2016: 44). 
својој - Свјетској револуцији, која је, како сам каже, негде на слободној територији, с Коминтерном. Сваке друге или треће ноћи, у касне сате, посећују га конспиратори Петсто прве, Четиристо деведесете, Триста седамнаесте црногорске армије! (...) Дон Грубан верује да су то прави борци, илегалци. Даје све што има!” (према MIKIĆ 1998: 170).

На тај начин, Малићев „Покрет” у контексту епистемичке структуре дела припада домену невидљивог, лажно креираног света, првобитно фундираног у Малићевој херојској уобразиљи, а додатно поткрепљеног обманама других јединки стварног света текста.

\section{5. Алетичка артикулација: фузија онтолошких модела}

Алетички модел фикционалног света оба романа формиран је као двокомпонентна онтолошка структура која у себи обједињује два домена - природни и натприродни. Користећи сличну дихотомију реалног и фантастичног за алетичко структурирање света као у првом обрађиваном роману, Булатовић и овде активира разноврсна семантичка поља гротескног и делиричног фантастичног дискурса чврсто позиционираног у оквире реалистичког логоса. Већ познати пишчев поступак „метаморфирања реалистичког детаља” или ситуације у нови, обично фантастични квалитет (LALIĆ 1968: 340) успоставља познату релацију реалног и фантастичног у виду паралелно егзистирајућих онтолошких антагонизама.

У роману Херој на магариу и Рат је био бољи, како је већ наглашено, основну алетичку матрицу представља природни фикционални свет обликован по узору на стварни, материјални, будући да оба романа грађу за фикционално конституисање стварног света текста црпе из реалне историјске ситуације. Стварни свет на тај начин једном делом учествује у обликовању алетичке структуре дела, најпре везивањем за конкретно историјско време и трансмисијом историјских дешавања и ликова у фикционални универзум текста. Реалистичко заснивање фикционалног света посебно ће доћи до изражаја у роману Херој на магариу тематизовањем ратне стварности у Бијем Пољу у периоду 1943. године, док је други роман Pam је био бољи у односу на први обележен већим удаљавањем од реалитета. Коришћење реалистичког модела константовано је и у критици: „(...) у Хероју на магариу нису само ликови убедљивије реалистички представљани, него овде Булатовић више неголи икад раније и икад касније користи наративне процедуре традиционалног романа"(JEREMIĆ 1997: 236). Свакако, у погледу алетичке редистрибуције оператора, оба романа поседују мотиве паралелне стварности и аспекте хибридизације светова, чија је модална опозиција неутралисана инфилтрирањем фан- 
тастичних елемената у реалну поставку збивања, у којој добијају статус новог, бизарног и гротескног типа стварности.

Већ су почетне странице романа Херој на магариу обележене једним фантастичним, виртуелним искораком из природног поретка света који представља основу фикционалог система дела. Приповедачево пародијско и иронично поигравање са нарцизмом пуковника Алегретија учинило је да паралелно са Алегретијевим развлачењем справе за растезање, једнодимензионалне слике историјских личности оживљавају, излазе из својих оквира и изражавају најдубљу солидарност и подршку пуковнику:

„Znoj je curio na sve strane, naročito po staklu: Benito Mussolini je izlazio iz okvira i vukao čelik (...) kraljica Jelena stiže u postojbinu i već korača preko zida i pukovnikove ćudljive opruge. (...) Goli i znojavi su i vojnici i sve druge ruke što vuku, što muče i žele da pobede spravu. (...) Sa karte sveta otkide se nekoliko zemalja; bez reči potonuše u bledu vodu mora." (BULATOVIĆ 1967: 11)

Накратко оживљени свет предмета, међутим, нестаје истог тренутка када пуковник победи справу, па фантастична слика враћа своje реалне оквире: „I pre nego što niz telo opruži nabrekle ruke, pomagači pobegoše na zidove i u svoje prašnjave okvire (...)" (1967: 12). Овакви елементи фантастичног настају редистрибуцијом субјективних алетичких оператора и нису део кодексног алетичког модела, будући да сам приповедни глас у тексту сведочи о њиховој природи као о пуком конструкту пуковникове имагинације. Фантастичне слике настале у уобразиљи појединачних нестварних јединки не трансцендирају алетичка ограничења природног матичног света текста, већ се посматрају као типови интермедијарних 6 светова пропуштени кроз призму измењених стања свести романескних ликова. Сличан пример инкорпорирања надреалних елемената у глобалну структуру природног света текста представља и Малићево фантастично преображавање у магарца: „Drhtao je i osećao kako gubi svoje stare odlike. Dok se zov trube znojio i kidao (...) njemu je izrastao rep. Činilo mu se da na stopalima nije više imao izdrte vojničke cokule - bile su to rđavo potkovana magareća kopita” (1967: 246). Малићева фантазмагорија дата је, заправо, као гротескни и комични приказ бедног и поражавајућег доживљаја сопствене личности. Уклапање фантастичних слика у свакодневну, емпиријску матрицу мотивисано је различитим психичким егзалтацијама Булатовићевих јунака, који под утицајем померене, делиричне тачке гледишта конституишу различите врсте интермедијарних светова.

6 Свет у коме је контраст између природног и натприродног домена премошћен различитим формама психо-физичких стања (снови, халуцинације, лудило, наркотично стање) назива се интермедијарним светом (DOLEŽEL 2008: 124-142). 
Нарушавање фундаменталног онтолошког слоја кодексним операторима конституише други тип ирационалних и фантастичних слика, који у овим романима теку паралелно са реалним збивањима и имају равноправан статус у дихотомији на којој се заснива алетичко устројство текста. Булатовићеви текстови се на гротескно-пародични начин појављују као обједињујућа инстанца двају дискурса, при чему се брише граница између реалног и фантастичног, а готово сви неприродни и ирационални сегменти уклапају се у реални оквир збивања, чинећи један модално хетерогени фикционални свет. Такав је случај са сценом кречења варошице пред долазак генерала у роману Херој на магариу, која поприма фантастична обележја у оном тренутку када, по речима наратора, бива окречен и ваздух, и вода из чесме, и људи који живе у варошици: „Bilo ih je tridesetak, i sve su bile okrečene (...) general iz zemljane posude pije i prosipa belu vodu (...) Gledao je kako general vadi iz džepova neke hartije i kako čita: beli su bili listovi, bele su bile reči, beo i vlažan bio je generalov jezik." (1967: 274-276) Симболичка сугестија болесне белине представља готово парадигматичан пример Булатовићевог иновирања фантастичног обрасца, који је у оба романа подређен поступцима симболизације и хиперболизације, као и општој тенденцији дела да свет прикаже путем инверзивне гротескне и карневалске логике. У складу са честим Булатовићевим претензијама експериментисања са наративним облицима и концептима, овде уочавамо моделовање једног природног, просторновремески конкретизованог света са свим елементима реалистичног проседеа, који специфичном булатовићевском фантастиком у више наврата бива разграђен и лишен сваке миметичке и емпиријске логике.

Гротескно кодирање текста моделује натприродни алетички домен, који у првом роману најчешће обухвата гротескно хипертрофирање делова тела јединки из стварног света текста, како би се нагласила алетичка обдареност фикционалних егзистената света или надоградили симболички идентитети романескних јунака. Хиперболизација у служби надреалних алетичких наноса овде иде у смеру гротескног абнормалног нарастања делова телесне целине, или целог тела уопште. Идући трагом раблеовске гротеске тела, Булатовић свог Грубана Малића обликује као антихероја са фалусом који нараста „до чудовишне величине”. Гротескна топографија тела у оба романа експлицира познато карневалско материјално-телесно начело и сведочи о надмоћи тела и натуралистичких анималних порива у човеку над духовном, божанском компонентом. Тиме Булатовић употпуњује свој дијаболични фикционални универзум, a „гротескна анатомска фантастика последично доводи до изобличења тела, до његове дефигурације” (PIJANOVIĆ 2001: 253). Осим Грубана Малића, гротескно изобличење прати и описе других житеља света, укљу- 
чујући и људе и животиње. Тако Мустафи Агићу, главном месном шпијуну и доушнику, абнормално расте оно уво којим више прислушкује: „Agićevo desno uvo bilo je pet puta veće od levog. Prijatno sam iznenađen, nasmeši se major, a zatim dodate u sebi: Tako nešto sam i predviđao, ali ipak, to tvoje nesretno uvo trebalo bi da prestane da raste" (BULATOVIĆ 1967: 359). Већ поменути пример нарастања пушке Салватореа Паолонеа не подразумева хипертрофију тела, али такође спада у домен фантастичне хиперболизације, која разграђује првопостављени онтолошки модел алетичке структуре.

Гротескно-фантастична хипертрофија тела још је наглашенија у другом роману, Pam је био бољи, у којем се и Малићев наследник приказује као чудовиште с најдужим и најдебљим фалусом који је у Европи виђен. Истим поступком и милосница Амалија, како запажа Пијановић, стално расте због „опште трулежи и смрада”, као и лепотица Романа, „чији претерани раст има за последицу растеловљење. Тело, дакле, себе надраста, излазећи из своје уобичајене природне величине” (PIJANOVIĆ 2001: 253). Абнормални раст Романиног тела, тешког и по неколико тона, као и бизарно-хуморна слика порођаја у којој ће, уместо новорођенчета, из Романиног тела изаћи униформисани командант савезничких јединица, представља уплив оних надреалних сфера које су у алетичкој структури уређене кодексним М-операторима, и део су поменутог диспарантног онтолошког модела. Хиперболисање телесног у овом роману обухвата и животињски свет, па тако и Педутова корњача непрестано расте до ненормалних размера, а магарац Лука са предимензионираним фаличким симболом у гротескно-фантастичној сцени обљубљује развратног и помамљеног свештеника у ваздуху. Магарчев лет и сексуални чин на небу, снимљен објективом Жоржеве камере, као и оживљавање мртваца са гробља творе онај тип натприродног дискурса који обједињује фантастично и реално, сакрално и профано, високо и ниско, божанско и сатанско. Богохулна и скаредна дешавања на гробљу, Малићев симболички обрачун са крстом на цркви Сан Ђовани Батисте, опсцена апотеоза фалусу и ругање смрти чине оквир травестиране слике стварности, која зачудну ауторску стваралачку експресију окреће ка надреалном, фантазмагоријском и хтонском.

\section{6. Трансдукција фикционалних светова и ентитета}

Имајући у виду многоструке интертекстуалне релације које на имплицитни или експлицитни начин романи Херој на магариу и Pam је био боли успостављају са осталим књижевним остварењима светске културне баштине, требало би поменути и мрежу књижевних дела, њихових семантичких трагова и ентитета са којима се Булатовићева дела 
повезују, како на интензионалном тако и на екстензионалном нивоу. У том контексту, анализа фикционалних светова изабраног Булатовићевог корпуса намеће и сагледавање књижевне трансдукције (DOLEŽEL 2008), односно процеса којим се поменути романи са осталим књижевним делима повезују не само на нивоу структуре, већ и на нивоу фикционалних светова.

Булатовићеви романи, сагледани у контексту целине његовог књижевно-уметничког опуса, како је више пута истакнуто у критичкој рецепцији дела, најдиректније успостављају везу са збирком приповедака Ђаволи долазе (1955), тачније са приповетком Црн, чији фикционални свет представља предложак оног књижевног света који ће касније бити уобличен у романима Херој на магариу и Рат је био бољи:

„У том погледу, на нивоу теме и јунака, приповест Црн је наративни ембрион који ће се у преобликованом виду појавити и у поменутим делима (...) Интертекстуалном игром и наративним преплетима приповест „Црн” уграђена је у роман превасходно поступком парафразе и престилизације, разлиставањем фабулативног склопа приповести, надградњом њеног композиционог система, променом тоналитета и повећањем семантичке носивости прототекста, док је у роману тек рудиментарно препознатљива форма аутоцитата" (PIJANOVIĆ 2001: $218 ; 188)$.

Паралелизам се, пре свега, успоставља у фабулативним подударностима, сличностима јунака/приповедача из приповетке Црн и Грубана Малића, његове знатно разрађеније форме фикционалног ентитета, али и у инкорпорирању одређених мотива, ликова и епизода - прича о војнику Нину Ботонију и Исмети, лик Рашка, епизода о сељаку који покушава да од Италијана купи топ итд. Њихови изворни идентитети, односно прототипови фикционалних јединки који се појављују у Хероју на магариу, зачињу се у поменутој причи, где их по први пут срећемо у Булатовићевом опусу. Осим поменутих интертекстуалних верзија путујућих јединки, Булатовићева имагинација имплементирала је у фикционални свет романа и низ личности из стварног света, односно ликове који своје матичне идентитетске базе имају у стварности: писце Максима Горког и Пијетра Аретина и режисера Виториа де Сику, док је алузивно-пародичним путем у лику Леди Агате Кристли аутор успоставио транссве-

7 Типологију путујућих наративних јединки дала је Хилари Даненберг, која разликује три категорије: екстратекстуалне, интертеткстуалне, и интратекстуалне верзије ликова. Екстратекстуалне верзије обухватају јединке које имају прототип у реалним ликовима из стварности. Интертекстуалне верзије се односе на варијанте нестварних јединки у различитим фикционалним текстовима и жанровима. Интратекстуалне варијанте одговарају различитим верзијама ликова унутар самог текста, које припадају различитим подсферама - актуалним или виртуелним (DANENBERG 2008: 61). 
товну релацију са реалним ликом познате списатељице. Уводећи њихове екстратекстуалне верзије у фикционални свет романа Pam je био бољи, „Булатовић поступком мистификације проширује простор свог романа и чини дифузним, фингирано аутентичним и карикираним свет који тај простор насељава” (2001: 250).

Најочигледнија интертекстуална релација успостављена је са романом Дон Кихот Мигела де Сервантеса, на чијем се фону обликује лик Грубана Малића и прича о његовим авантурама. Алузивна спона остварена је, пре свега, именом - Дон Кихот/Дон Грубан, затим и карикатурално-пародичном природом оба јунака, која витеза тужног лика приказује као пародију јунака витешког романа, а Булатовићевог витеза тамног лика као антијунака који се супротставља типичним херојима ратних романа. Паралела ових ликова и детаљно проучавани однос између Булатовићевог текста и његовог смисаоног супстрата у критичким анализама дела сумира закључак да, поред бројних разлика, и Сервантес и Булатовић обликују своје јунаке са идентичним циљем дестабилизације света и карактерних матрица ликова које типски представљају (2001: 204). Булатовићева реплика на чувену драму Чекајући Годоа Семјуела Бекета омогућила је трансдуктивни пренос фикционалних ентитета Бекетовог дела у епилог романа Pam је био бољи, где се, осим интертекстуалних панданских верзија Владимира, Естрагона, Поцоа и Лакија, у сугестивном виду појављује и Бекетов лик, као капетан маскираног ирског брода по имену Арчибалд Бекет. Семантичке импликације ове Булатовићеве епизоде реплицирају Бекетову метафизичку фарсу, поготово у контексту њене повезаности са филозофијом егзистенцијализма, сугеришући један полемички однос према човековом покушају да се на било који начин отргне времену и историјском току: „Отуд је Булатовићев човек као трпно стање историје бешчашћа увек на губитку, то јест јунак пораза (...)” (2001: 273).

\section{7. Закључак}

Применом теорије модалних система у анализи наративних светова који постоје у наведеним романима, испитивањем њихове наративне структуре, односа стварности и фикције, устројства реалних и фантастичних равни, предочене су стратегије које Булатовић користи како би конструисао могуће светове својих дела. Уочена релација семантике фикционалног и теорије текста, различити видови поступка аутентизације која манипулише фикционалном егзистенцијом, као и метафикцијска подривања, односно урушавања аутентичности фикционалног света, део су специфичне, булатовићевске логике фикције, карактеристичне за готово цео његов опус. 
Удвајање фикционалних светова истражено је приликом анализе литерарне мистификације изворног прото-текста у роману Херој на магариу, тј. уочавањем паралелног света који фигурира у примени филмске технике у нарацији романа Pam је био бољи. Такође, у раду је сагледан смисао постајања виртуелне стварности и њен удео у профилисању пародијске и карневалске слике света, са посебним освртом на елементе карневализације, који су доминантно заступљени у Булатовићевој стваралачкој визији. Тема рата се у одабраним Булатовићевим романима даје превасходно у еротској и карневалско-обредној представљачкој форми. Сталне варијације бинарних структура осликавају симбиозу узвишеног и ниског, која у гротескној абмивалентности обликује једно поразно стање стварности.

Анализом деонтичких параметара који уређују светове романа испитани су начини конструкције социјално-културног устројства Булатовићевих књижевних светова, који у свим делима експлицирају конфликт кодексних и субјективних деонтичких модалитета. Сукоб друштвено наметнутих норми и субјективних моралних стремљења ликова поприма велике размере у оба романа, будући да ратна/поратна ситуација остаје главни модулатор фикционалних збивања.

Проучавањем аксиолошког поретка романескних светова уочена је диспропорција колективне аксиологије и личних аксиологија ликова, која је најчешће и извор њиховог (ауто)деструктивног деловања. Сви Булатовићеви светови успостављају нови, инверзивни тип аксиологије, уобличене на подлози релативизације и разарања традиционалних аксилошких образаца и култова успостављених колективном свешћу. Један део рада дотакао је и поетику страности и различите врсте разграничавања паралелно егзистирајућих светова, чија сложеност иде у правцу приказа различитих нација, вера, култура, идеологије, друштвених класа и др. Истраживањем епистемичког моделовања фикције у романима указано је на методе ширења семантичког језгра и динамизацију приказаних збивања креирањем лажног, идеолошки сенченог света, заснованог у херојској уобразиљи главног Булатовићевог антијунака.

У поглављу посвећеном алетичкој структури светова примећено је да је за Булатовићеве романсијерске приче карактеристичан реални оквир, приказ реалистичке средине и збивања (уз честу евокацију локалне боје), у који се уводи неко ирационално начело и успоставља надреална релација, као парадигма нове, фантастичне стварности. У таквој нарацији фантастична и реална збивања егзистирају паралелно, при чему се граница између ове две равни брише, те они сачињавају један дијаболични универзум са мноштвом интермедијарних светова. Према томе, инкорпорирањем интермедијарних и натприродних домена у своју 
алетичку структуру, Булатовићеви фикционални светови праве својеврсни отклон од очекиване миметичке доктрине реалистичког приказа, а спрега миметитичког и фантастичног омогућава функционално срастање у вишедимензионалном свету књижевног текста.

Као и већина пишчевих прозних остварења, овај диптих представља плодно тло и за истраживање интрауниверзумских световних релација формираних на односу стварног света текста и његових многоструких виртуелних домена, сведочећи о значајном учинку који се разноврсним фикционалним световима постиже у погледу дестабилизације реалности, што, иначе, представља једну од Булатовићевих доминантних стваралачких интенција.

\section{Цитирана литература}

BULATOVIĆ 1967: BULATOVIĆ, Miodrag. Heroj na magarcu. Rijeka, 1967.

BULATOVIĆ 1986: BULATOVIĆ, Miodrag. Rat je bio bolji. Beograd: Beogradski izdvavačko-grafički zavod, 1986.

DANENBERG 2008: DANNENBERG, Hilary P. Coincidence and Counterfactuality, Plotting Time and Space in Narrative Fiction. Lincoln and London: University of Nebraska Press, 2008.

DOLEŽEL 1997: DOLEŽEL, Lubomir. „Mimezis i mogući svetovi”. Reč, br. 30, februar 1997, str. 74- 82.

DOLEŽEL 2008: DOLEŽEL, Lubomir. Heterokosmika. Beograd: Službeni glasnik, 2008.

JEREMIĆ 1978: JEREMIĆ, Ljubiša. Proza novog stila. Beograd: Prosveta, 1978.

JEREMIĆ 1997: JEREMIĆ, Ljubiša. „Miodrag Bulatović, u srpskoj književnosti”. Stvaranje, časopis za književnost i kulturu, LII, BR. 1/5, 1997.

LALIĆ 1968: LALIĆ, Ivan. „Tragom jedne romansijerske dileme”. Letopis Matice srpske, Нови Сад, 1968, str. 338- 343. [orig.] ЛАЛИЋ, Иван. „Трагом једне романсијерске дилеме". Летопис Матице српске, Нови Сад, 1968, стр. 338- 343.

MARGOLIN 1997: MARGOLIN, Juri. „Jedinke u narativnim svetovima: jedna ontološka perspektiva”. Reč, br. 30, (februar 1997), str. 88- 100.

MIKIĆ 1998: MIKIĆ, Radivoje. „Rat kao karneval. O romanu Heroj na magarcu Miodraga Bulatovića". Srpski roman i rat, priredio Miodrag Maticki, Naučni skup Despotovac, 1998. [orig.] МИКИЋ, Радивоје. „Рат као карневал. О роману Херој на магарцу Миодрага Булатовића”. Српски роман и рат, приредио Миодраг Матицки, Научни скуп Деспотовац: Библиотека Ресавска школа, 1998.

MILOSAVLJEVIĆ MILIĆ 2016: MILOSAVLJEVIĆ MILIĆ, Snežana. Virtuelni narativ. Filozofski fakultet Univerziteta u Nišu: Niš, 2016.

PIJANOVIĆ 2001: PIJANOVIĆ, Petar. Poetika groteske: pripovedna umetnost Miodraga Bulatovića. Beograd: Narodna knjiga - Alfa, 2001. [orig.] ПИЈАНОВИЋ, Петар. Поетика гротеске: приповедна уметност Миодрага Булатовића. 
Београд: Народна књига - Алфа, 2001.

RIBNIKAR 1997: RIBNIKAR, Vladislava. „Mogući svetovi i teorija fikcije”. Reč, br. 30, (februar 1997), str. 69-73.

ŠUKALO 2002: ŠUKALO, Mladen. Odmrzavanje jezika: poetika stranosti u djelu Miodraga Bulatovića. Banja Luka: Grafid, Beograd: Prosveta, 2002. [orig.] ШУКАЛО, Младен. Одмрзавање језика: поетика страности у дјелу Миодрага Булатовића. Бања Лука: Графид, Београд: Просвета, 2002.

TOMIĆ 1998: TOMIĆ, Lidija. „Tipološko određenje romana Rat je bio bolji”. Književnost $i$ jezik, god 46, br.1, 1998, str. 39-45. [orig.] ТОМИЋ, Лидија. „Типолошко одређење романа Рат је био бољи”. Књижевност и језик, год 46, бр.1, 1998, стр. 39-45.

TOMIĆ 2005: TOMIĆ, Lidija. Groteskni svijet Miodraga Bulatovića. Nikšić: Jasen, 2005. [orig.] ТОМИЋ, Лидија. Гротескни свијет Миодрага Булатовића. Никшић: Јасен, 2005.

Hristina Lj. Aksentijević

\section{BULATOVIĆ'S LOGIC OF FICTION: POSSIBLE WORLDS IN THE NOVELS HERO ON A DONKEY AND WAR WAS BETTER BY MIODRAG BULATOVIĆ}

The research subject of the paper Bulatovićs logic of fiction: possible worlds in the novels Hero on a Donkey and War Was Better by Miodrag Bulatović is the separation and analysis of the fictional worlds and characters in Bulatovićs novels, thus relying on the basic postulates of the possible worlds theories and the works of the leading authors dealing with this field in the science of literature. The topic provides many opportunities for innovation, as it deals with under-explored aspects of $\mathrm{Bu}$ latović's prose, which remain out of focus of literary-critical literature. The corpus consists of MiodragBulatović's two novels: Hero on a Donkey (1967) and The War Was Better (1969). The basic methodological orientation is represented by classical and post-classical narratological studies, with a particular focus on cognitive narratological research.

Keywords: theory of possible worlds, fictional world, fictional units, metafiction, novel, Bulatović 